\title{
The use of flat steel-polymer supporting ropes in mining multi-pole hoisting devices
}

\author{
Michał Stawowiak, Marcel Żołnierz \\ Silesian University of Technology, Poland \\ Zenon Rożenek \\ KAZ Serwis Sp. z o.o. Gliwice, Poland
}

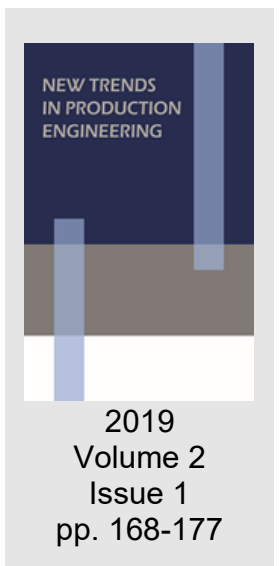

Date of submission to the Editor: 05/2019

Date of acceptance by the Editor: 07/2019

\section{INTRODUCTION}

In the world mining, in the transport shafts transporting people, materials and mines useful energy. In Poland, hoisting devices with a drive or drum drive (single or double drum) are used as mining hoisting devices. The popularity of the above mentioned drives depends on different from tradition. In mining used by about $33 \%$, a device with a drive is created, so-called Koepe lifting devices. As a carrier for hoisting ropes (lorry), one or two-wheel drive wheels and multirope drums are used in these devices, in Poland an even number of no more than 2 or 4 . In the world, multi-rope drums are used with even or odd ropes: 3 , 4, 5, 6, 7, 8, 10 and 12 (Żur and Hardygóra, 1996; Haskus and Szołtysik, 1982; Hankus, 2000).

Extraction machines with friction drive can be located on the frame (machines $1,2,3,4,5,6$ rope) or on the tower (machines 1, 2, 3, 4, 5, 6, 7, 8, 10 and 12 rope). The popularity of using mining friction drive hoists results from their basic advantage resulting from the necessity of using balance ropes. In this case, due to the static balancing of the weight of the lifting and compensating ropes and the own weight of the extraction vessels, the power of the winding machine is only needed to transport the payload of the extraction vessel and to overcome the lift resistance of the lift. The diameters of supporting ropes in the monolithic extracts reach $76 \mathrm{~mm}$, and in multi-rope ropes up to $60 \mathrm{~mm}$. Lifting capacity reaches $60 \mathrm{Mg}$, depending on the type of transported spoil. One of the most important parameters determining the geometrical dimensions of the wheel or propeller is the diameter of the rope $d$. The diameter of the Dp wheel or drum should meet the requirements imposed by Polish mining regulations $D p / d \geq 80$. In global mining it is recommended that $D p / d \geq 90-110$ (usually 100), depending on the design of the rope. For the parameter $D p / d=100$, the diameters of the wheels or drums reach up to 9 meters. Significant diameters of wheels or propeller drums significantly affect the power of hoisting machines (increase in moments of inertia of rotating elements of the hoisting device, thus increasing the load torque) and the weight of the springs. It should be noted that until now 
only steel steel lifting ropes have been used as lifting ropes in mining hoisting machines with friction drive, and in flat bobbin extracts, flat steel riveted or riveted ropes (Wojczyk, 2005).

In Poland, since 1988 in mining, SAG steel and rubber balance ropes have been successfully used. The SAG steel and rubber balancing ropes last up to 12 years. In these ropes in the rubber coating, 2 to 8 wire ropes are vulcanised with diameters: 12, 14, 16, 18, 20, 22, 24 mm (Carbogno, 1992; Carbogno, 1994; Carbogno, 1995; Carbogno, 2000; Carbogno, 2002). In the case of friction drives, very high durability of these ropes (very high corrosion protection - ubber coating) and a significant amount of small steel ropes in the SAG lines, resulting in a reduction in the diameter of the wheel or the propeller, underlie the analysis of the possibilities and assessment of the use of flat steel ropes-polymeric as load-bearing ropes in mining friction-driven mining devices. Of course, the influence of various parameters on the durability and behavior of load-bearing steel-polymer rope ropes, which in this article is called NPSP ropes (loadbearing, flat, steel-polymer), should be analyzed (Hansel, et al., 1990).

The use of NPSP lifting ropes can also contribute to the elimination of mining hoist slip friction drives during mining operation due to the greater coefficient of friction between the NPSP rope and the wheel liner compared to classic solutions. The present article is mainly concerned with the comparison for two cases of multi-rope hoist with a propeller drum, in which steel round wire ropes have been replaced with NPSP type ropes. The analyzes were carried out for the technical and operational parameters of the four-cylinder hoisting device with a propeller drum with a diameter of $3000 \mathrm{~mm}$ and a power of $1800 \mathrm{~kW}$ operated in the selected mine shaft of the mining plant (due to the large number of calculations, they were not published in full in this article). The issue of the use of flat steel and polymeric hoisting ropes using a rubber polymer is already presented in (Carbogno, 2002; Carbogno, 2003). The use of a steelpolyurethane lifting rope is presented in (Burda, 2004; Kędziora, 1983).

Figure 1shows a picture of a steel-polymeric carrying rope.

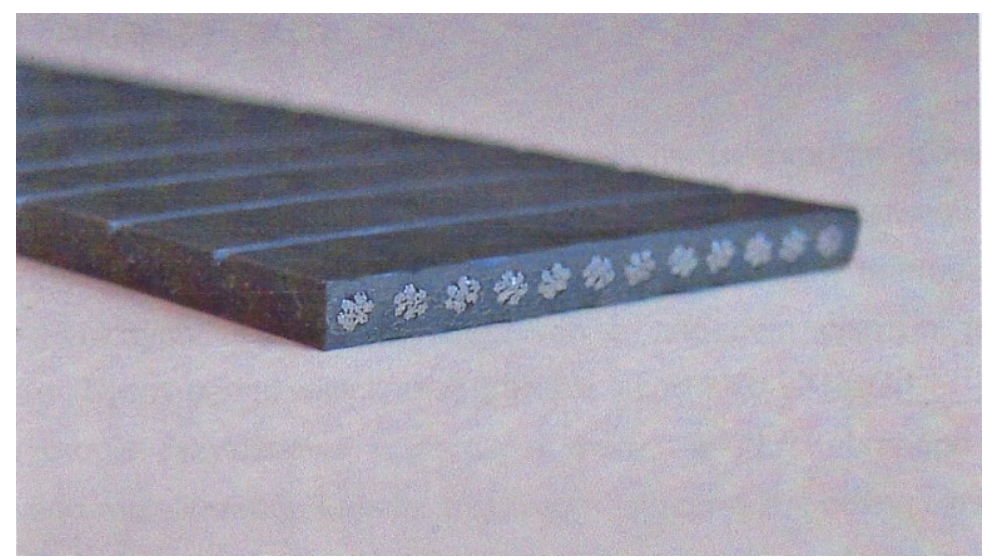

Fig. 1 Steel and polymer carrying rope

Source: (Brochures, 2000) 


\section{OVERVIEW OF THE STATE OF THE ART IN THE FIELD OF USING FLAT STEEL AND POLYMER SUPPORTING ROPES}

The first publications on the use of flat steel and rubber ropes as load-bearing ropes in mining shaft hoists appeared in the 1970s in Russian technical literature, these were proposals of Ukrainian research centers and universities. In those years, there was a trend in the global mining industry for the maximum extraction of useful minerals from large depths. This mainly concerned various types of ores and hard coal. The increase in the efficiency of mining hoisting equipment can be achieved by the use of lifting vessels of high capacity, at high speed, which in the global mining does not exceed $20 \mathrm{~m} / \mathrm{s}$. In order to ensure economically viable extraction at great depths, the use of hoisting equipment in vertical transport was considered with a useful lift capacity of skips 800-1200 $\mathrm{kN}$, and in transport inclined in open-pit mining, skips with a lifting capacity of 1000-3000 kN. Such assumptions caused that flat steel-rubber ropes, depending on the lifting capacity of the useful lift and the number of ropes, would have to be $0.5-3 \mathrm{~m}$ wide. Practically, these ropes would be the equivalent of conveyor belts with steel cables. Just rewinding such wide flat steel and rubber ropes, eg in a one-rope hoist with a width of 0.8-2 $\mathrm{m}$, and in a polyline from 0.5 $0.8 \mathrm{~m}$, with a few ropes it would probably create great difficulties in the operation of such ropes.

In 1988, a publication was published, in which the concepts of single and multirope statements developed in Great Britain were presented. These concepts concerned extracts with a small useful capacity, but with a high drawing depth. They were extracts for drawing ore or for transporting materials and machines. In place of steel wire ropes, flat steel and rubber ropes were proposed, which are shown in Figure 2 (Wojczyk, 2005).

A

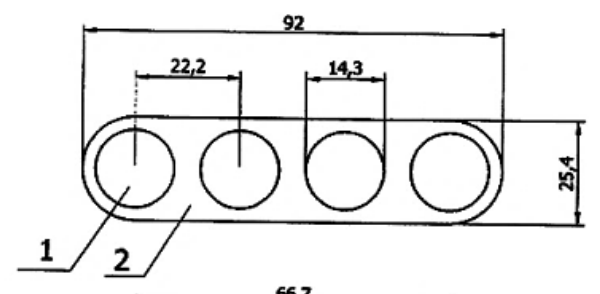

B

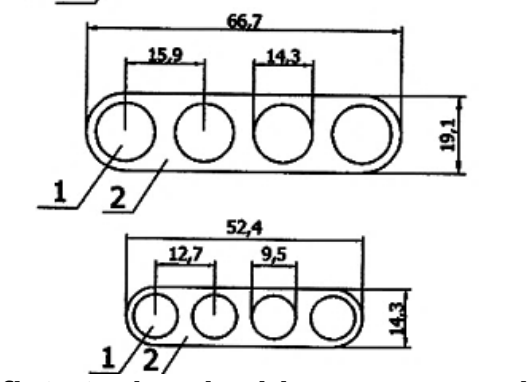

Fig. 2 Cross sections of flat steel and rubber ropes used in Great Britain: 1 - steel ropes, 2 - rubber coating

Source: (Wojczyk, 2005)

Two concepts of exhaust equipment proposed in (Black, 1988) are presented below. The use of flat steel-rubber bearing ropes is provided in deep wells with 
lengths of hanging branches of supporting ropes, I = $1220 \mathrm{~m}$. Schemes of classic extraction devices are shown in Figure 3 (Wojczyk, 2005).
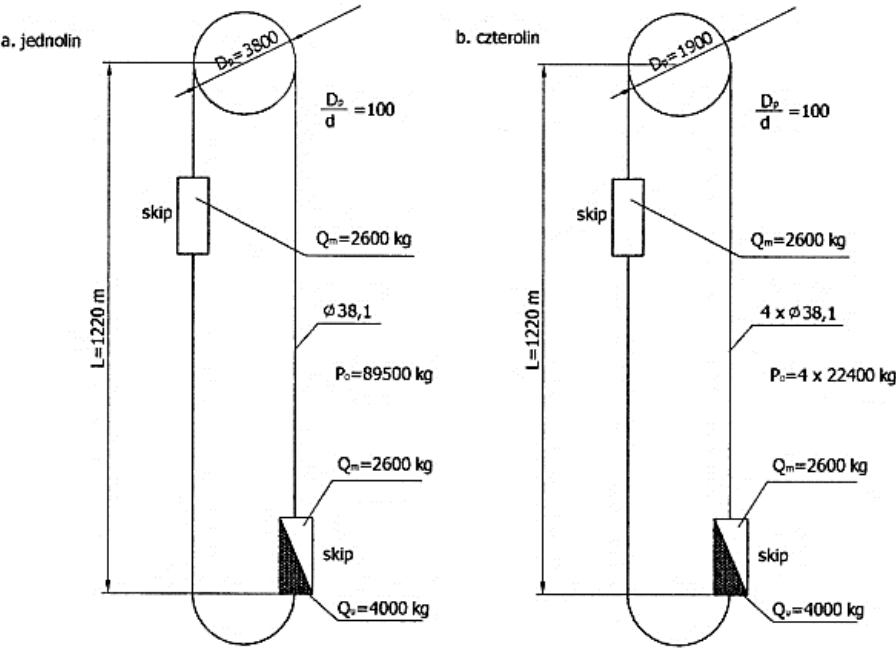

Fig. 3 Schemes of classic hoisting equipment with round ropes:

a - single-rope hoist, b - four-rope lift, $\mathbf{Q}_{m}, \mathbf{Q}_{\mathbf{n}}$ - dead and useful mass of skip Source: (Wojczyk, 2005)

These devices were replaced with devices with flat steel and rubber bearing ropes. The single-rope hood uses NPSP rope measuring $98.5 \times 27 \mathrm{~mm}$ with 4 ropes with a diameter of $19.1 \mathrm{~mm}$ and a force breaking the rope $P_{0}=1200 \mathrm{kN}$. Pressure between ropes, and the drive wheel is calculated according to the following formula (Wojczyk, 2005):

$$
\mathrm{p}=\frac{\mathrm{S}_{1}+\mathrm{S}_{2}}{\mathrm{D}_{\mathrm{p}} \times \mathrm{w} \times \mathrm{d}}=\frac{19570+15570}{190 \times 4 \times 1,9}=24,34 \frac{\mathrm{kG}}{\mathrm{cm}^{2}} \approx 2,43 \mathrm{MPa}
$$

where:

$\mathrm{S}_{1}, \mathrm{~S}_{2}$ - forces in the branches of the rope $[\mathrm{N}]$,

$\mathrm{D}_{\mathrm{p}}$ - diameter of the transaxle [mm],

$\mathrm{w}$ - the number of ropes in a flat line,

$\mathrm{d}-$ rope diameter $[\mathrm{mm}]$.

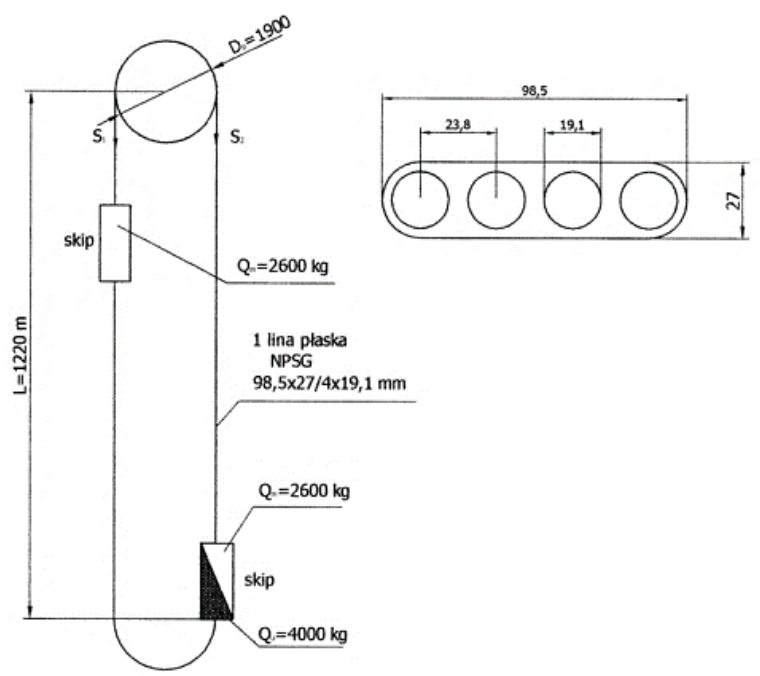

Fig. 4 Scheme of a single rope hoisting device with flat steel and rubber bearing ropes:

Source: (Wojczyk, 2005)

$Q_{m}, Q_{n}-$ dead and useful mass of skip 
The original concept was used in a multi-rope extractor, where one large fourcylinder drum was replaced with two small diameter quadricols. There are four NPSP carrying ropes on each drum with dimensions of $52.4 \times 14.3 \mathrm{~mm}$ with four ropes with a diameter of $9.6 \mathrm{~mm}$ each. In fact, it is an eight-string lift. The force breaking one rope is $P_{o}=896 \mathrm{kN}$. The unit load of ropes is (Wojczyk, 2005):

$$
\mathrm{p}=\frac{\mathrm{S}_{1}+\mathrm{S}_{2}}{\mathrm{D}_{\mathrm{p}} \times 4 \times \mathrm{d}}=\frac{13160+11160}{99,1 \times 4 \times 0,96}=16 \frac{\mathrm{kG}}{\mathrm{cm}^{2}} \approx 1,6 \mathrm{MPa}
$$

where:

$\mathrm{S}_{1}, \mathrm{~S}_{2}$ - forces in the branches of the rope $[\mathrm{N}]$,

$D_{p}$ - diameter of the transaxle [mm],

$\mathrm{d}$ - rope diameter $[\mathrm{mm}]$.

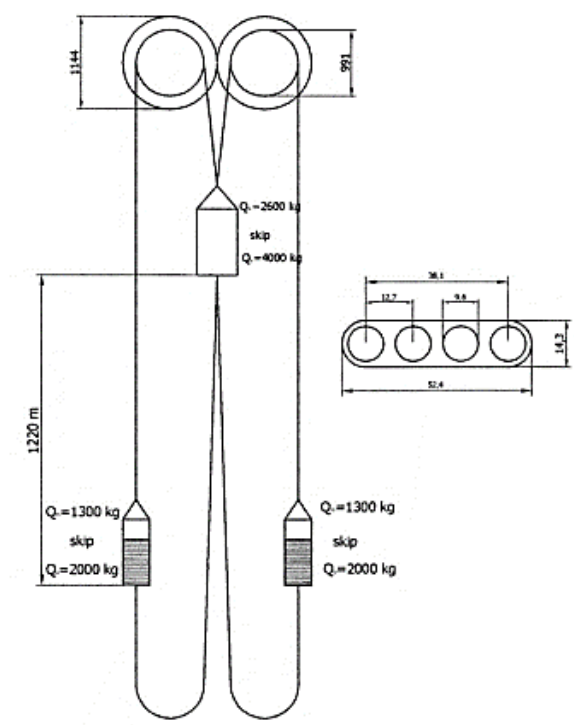

Fig. 5 Scheme of eight-rope lift with two four-cylinder drums and flat steel-rubber lifting ropes: $\mathbf{Q}_{\mathrm{m}}, \mathbf{Q}_{\mathbf{n}}$ - dead and useful mass of skip Source: (Wojczyk, 2005)

The analysis shows that the unit loads of ropes in NPSP ropes on the circle or drum groove are $p=1.6-2.43 \mathrm{MPa}$, so they are very large. In the English study there is no information on permissible pressures.

In the solution used in the mining shaft hoist with flat steel and rubber flat ropes with a monofilament wheel, on the edge of two small drums with a diameter of $991 \mathrm{~mm}$, there are gears with a diameter of $1144 \mathrm{~mm}$. These wheels are used to drive one of the drums with the drive motor driving the second drum. The analysis shows that despite the reduction of the diameter of the wheel and the propelling drum, the capacity of the winding machines in the considered cases are the same (about $800 \mathrm{~kW}$ ), only profit was obtained in the form of a reduction of exploitation costs to $42 \%$ (Wojczyk, 2005).

The concepts of Otis shaft extracts. The German company Otis used in its passenger lifts the flat ropes in which the steel ropes are coated with a Coated Steel Belt. The passenger crane with flat steel and polyurethane carrier ropes is shown in Fig. 6. These cranes were called cranes without machines (Brochures, 2000). 


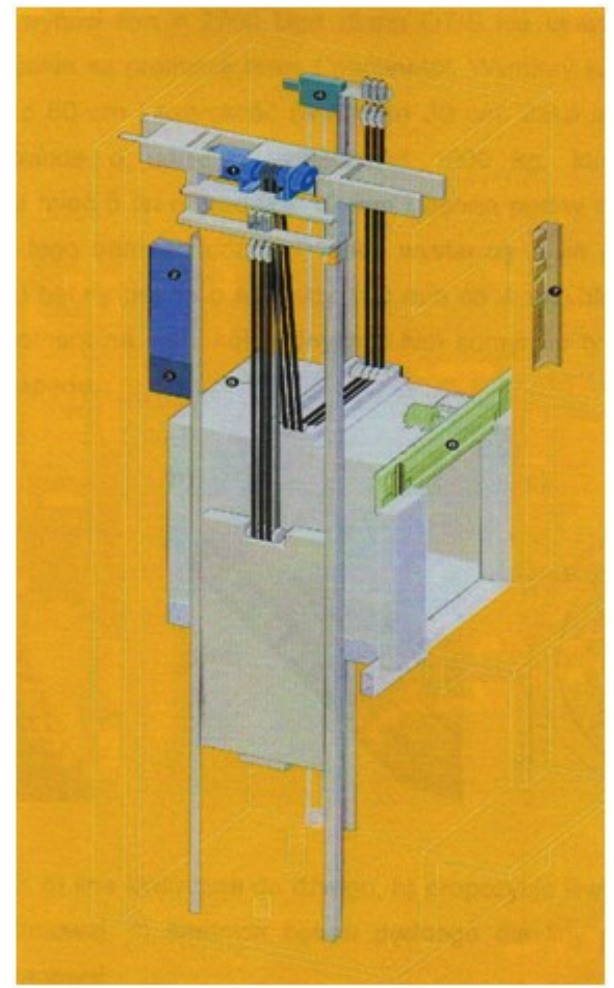

Fig. 6 Scheme of a passenger lift of the OTIS company using flat steel-polyurethane lifting ropes:

1 - compact crane drive, 2 - crane control system, 3 - crane remote monitoring system, 4 - precise speed limiter, 5 - lifting ropes flat steel-polyurethane,

6 - speed-controlled door drive, 7 - emergency and reversing controller Source: (Brochures, 2000)

As a supporting rope, a steel-polyurethane rope with dimensions of $30 \times 3 \mathrm{~mm}$ was used.

In this line there are 12 lines with a diameter of $2 \mathrm{~mm}$, construction $7 \times 7$ (Figure 7b), in a flat line there are 588 steel wires.

a)

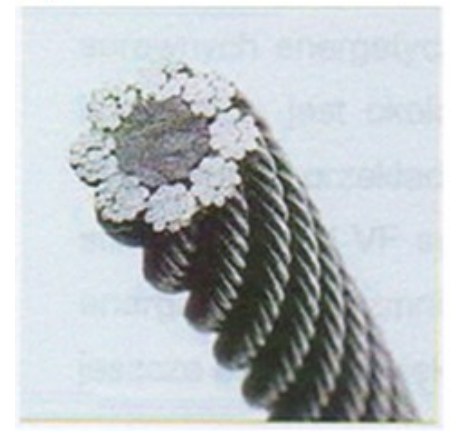

b)

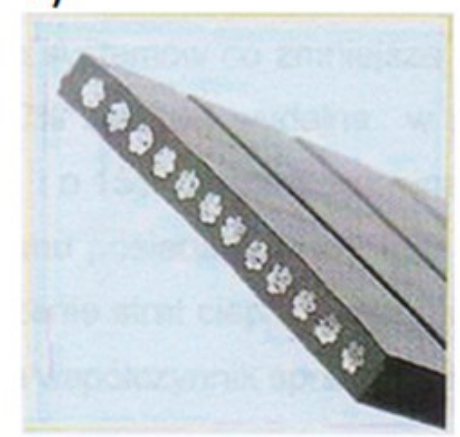

Fig. 7 Rope views: c)

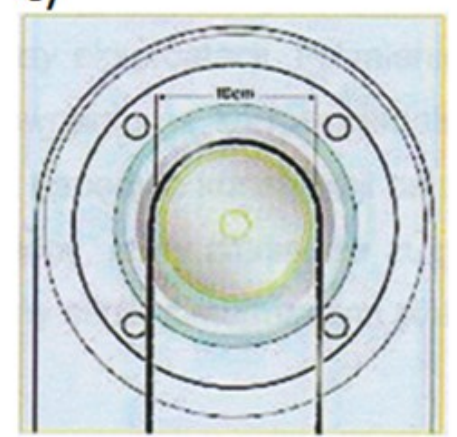

a - classic rope used in cranes, b - flat polyurethane rope, c-diameter of the drum for a steel-polyurethane flat rope

Source: (Brochures, 2000)

For example, in a crane with a lifting capacity of $630 \mathrm{~kg}$ (8 people), three flat cables with dimensions of $30 \times 4 \mathrm{~mm}$ and three smooth wheels with a diameter of $100 \mathrm{~mm}$ each were used $(\mathrm{D} / \mathrm{d}=50$ or $\mathrm{D} / \mathrm{g}=100 / 3$, 
where:

$\mathrm{g}$ - thickness of flat rope).

The strength of the wire is likely to be $R_{m}=2700 \mathrm{MPa}$ (OTIS did not disclose the details). The flat ropes were manufactured by Continental. Dimensions of a specific drive are: length $-80 \mathrm{~cm}$, width (diameter) $\varnothing 30 \mathrm{~cm}$. As another example of a crane, a lift with a useful capacity of $1000 \mathrm{~kg}$ can be provided, which in the classic solution must have 6 ropes with a diameter of $10 \mathrm{~mm}$ and a propeller drum with a diameter of $420 \mathrm{~mm}(\mathrm{D} / \mathrm{d}=42)$. For the same load capacity, only 5 flat steel polyurethane ropes and $100 \mathrm{~mm}$ diameter propeller drums are needed, which approximately gives about 4 times less torque on the drive wheel shaft, and thus reduces the necessary drive power (Brochures, 2000).

Flat ropes with a thickness of only $3 \mathrm{~mm}$ and a width of $30 \mathrm{~mm}$, are more durable and more flexible than heavy steel ropes, which have been a standard construction for over a century. Flat ropes are also $20 \%$ lighter. Each flat rope contains more wires than a conventional rope, the use of 588 steel wires in each line guarantees its high durability. Thanks to the appropriate flexibility, the cables can be rewound on a friction wheel with a very small diameter. Each of the ropes can bear a weight of 360 daN, which means that with a minimum of 3 ropes, the Gen2 system provides the value of the rope safety factor $n=12$. The plasticcoated flat steel rope reduces the dimensions of the drive, which occupies only $30 \%$ of space occupied by a conventional drive together with the gear. The small dimensions of the Gen2 drive allow it to be placed in the headroom, thus eliminating the engine room space. The smaller winch also means less inertia of the rotating elements, which significantly reduces the energy consumption during the crane start-up. The maintenance-free disc brake reduces the reliability of the crane drive. The polyurethane coat also provides better than in the case of conventional ropes frictional coupling, which allows for more efficient transmission of drive power to the moving booth. The flat rope also has a larger contact surface, which significantly reduces the wear of the drive wheel.

\section{CONCLUSION}

The development of mining construction of hoisting equipment also includes the use of new rope ropes. Very positive results from mining in Polish mining, flat steel and rubber balance ropes (durability up to 12 years), can be the basis for using such ropes as supporting ropes. Flat steel-polymer supporting ropes, in which the matrix can be rubber or polyurethane or other plastic material, could contribute to increasing the durability of load-bearing ropes due to anti-corrosion protection as well as to reduce the dimensions of drive wheels and rope hoisting machines, and thus to lower the power of the winding machine (as a result of reducing the moments of inertia of the propeller, propulsion and rope) (Wojczyk, 2005; Żur and Hardygóra, 1996; Kwaśniewski, 2010).

This article presents a proposal to use flat steel - polymer supporting ropes instead of round ropes. A series of NPSP ropes is presented, in which the overall dimensions of such a rope, the number and diameter of ropes, as well as the breaking strength of the rope are included. The proposal also presents the use 
of flat steel and rubber ropes in other countries, such as Russia, the United Kingdom and Germany.

The following conclusions can be drawn from the analysis:

- constructions of mine hoisting equipment with multi-shaft friction drive using NPSP ropes may be identical,

- from the analysis of the polyurethane properties, it appears that when using a polyurethane matrix, the permissible rope forces on the drive wheel $p_{d o p}=$ $2 \mathrm{MPa}$ are important for the durability of NPSP ropes,

- the proposed series of supporting ropes covers the dimensional range of the cross-section of ropes from $92 \times 18 \mathrm{~mm}$ to $424 \times 30 \mathrm{~mm}$, using rope diameters from $10-22 \mathrm{~mm}$ and their number in lines from 6 to 16 pieces. For practical purposes, it is recommended to use ropes with dimensions and width up to $300 \mathrm{~mm}$,

- from the comparative analysis of NPSP ropes with popular round triangular bridge ropes, it follows that with the same unit mass above a certain value, the breaking force of the NPSP rope is from $15 \%$ to $100 \%$ higher than that double-stranded ropes, which is a great advantage of NPSP ropes,

- NPSP ropes should be made of steel cables with minimum wire strength $R_{m}$ $=2060 \mathrm{MPa}$. The higher the strength of wires $\left(R_{\mathrm{m}}\right.$ to $\left.2260 \mathrm{MPa}\right)$, then we obtain ropes with smaller lateral dimensions and unit weight,

- from the analysis of the literature, it appears that OTIS passenger lifts are already used in the form of steel and polyurethane flat ropes with very positive results of their operation,

- the calculation of the power of the analyzed winding machine (due to the complexity of these calculations, their results are not presented in this article) shows that when the diameter of the transaxle changes to $D_{p}=1600 \mathrm{~mm}$, the required power is by $11 \%$ less than the power output variant with ropes steelround carriers,

- the use of hoisting machines with small diameters of the propeller drums, which correspond to the distance between the axes of the extraction vessels in the panes, eliminates the imprint wheels, which negatively affect the durability of the lifting ropes due to the forced bi-directional bending,

- from the analysis of the unit pressure of the NPSP rope on the propellant liner, it results that $p$-unit pressures below the permissible pressures can be obtained $p_{\text {dop }}=2 \mathrm{MPa}$, differentiating the number of carrying ropes,

- from the analysis of the rope confidence coefficient before slipping on the propeller, it follows that for a coefficient of friction above $\mu=0.25$ and a wrap angle $\alpha=180^{\circ}$, the friction coefficient $\mu$ is always higher than the required value $\mu_{\mathrm{w}}=1.3$,

- on the basis of the information contained in this article, it can be concluded that there is a real possibility of using NPSP ropes in mining multi-rope extracts while obtaining measurable economic effects. 


\section{REFERENCES}

Black, G.A. (1988). Unconventional hosting systems. In: International Conference on Hoisting of Men, Materials and Minerale. Toronto, Ontario, Canada: pp. 519-551.

Brochures of the OTIS company. (2000). Gen2 system.

Burda, S. (2004). Porównanie mocy napędu górniczego urządzenia wyciągowego jednolinowego z liną nośną stalową okrągłą i liną nośną płaską stalowopolimerową. Praca dyplomowa. Gliwice: Instytut Mechanizacji Górnictwa Politechniki Śląskiej.

Carbogno, A. (1992). Rozwój konstrukcji i zastosowania lin wyrównawczych płaskich stalowo - gumowych. Biuletyn informacyjny BIKT-SAG, 2(7), pp. 30-39.

Carbogno, A. (1994). Naciski poprzeczne na linę płaską stalowo-gumową. Biuletyn informacyjny BIKT-SAG, 2(7), pp. 45-52.

Carbogno, A. (1995). Badania własności mechanicznych lin wyrównawczych płaskich stalowo - gumowych SAG. Biuletyn informacyjny BIKT-SAG, 3(8), pp. 37-45.

Carbogno, A. (1994). Badania sprawdzające własności mechaniczne płaskiej liny wyrównawczej stalowo - gumowej. Praca NB-4/GR-2/94. Gliwice: Instytut Mechanizacji Górnictwa Politechniki Śląskiej.

Carbogno, A. (2000). Zawieszenia i zaciski lin wyciągowych płaskich stalowogumowych. Praca BW-528RG-2/2000/T1. Gliwice: Instytut Mechanizacji Górnictwa Politechniki Śląskiej.

Carbogno, A. (2002). Bobin drum hosting with flat steel - rubber cated ropes. In: $1^{\text {st }}$ International Conference Logistics And Transport LOADO. Kosice: ICLAT LOADO, pp. 157-166.

Carbogno, A. (2002). Górnicze urządzenie wyciągowe z kołem pędnym i linami nośnymi płaskimi stalowo-gumowymi NPSP. Gliwice: Instytut Mechanizacji Górnictwa Politechniki Śląskiej.

Carbogno, A. and Czaplicki, J. (2003). Frictionhoists with steel - rubberflatheadropes. In: $2^{\text {nd }}$ International Conference Logistics And Transport LOADO. Kosice: ICLAT LOADO, pp. 147-158.

Carbogno, A. (2003). Urządzenia wyciągowe Koepe z linami nośnymi płaskimi stalowogumowymi. Szczyrk: Międzynarodowa Konferencja Naukowo Techniczna Transport Szybowy 2003, Centrum Mechanizacji Górnictwa KOMAG, pp. 88-97.

Hankus, J. and Szołtysik, P. (1982). Metoda oceny czasu pracy lin w oparciu o wskaźnik meganiutonometrów. Katowice: Główny Instytut Górnictwa.

Hankus, J. (2000). Budowa i własności mechaniczne lin stalowych. Katowice: Główny Instytut Górnictwa.

Hansel, J., Kwaśniewski, J., Lankosz, L. and Tytko, A. (1990). Badania magnetyczne lin stalowych. Kraków: Wydawnictwo Akademii Górniczo Hutniczej.

Kędziora, A. (1983). Eksploatacja szybowych urządzeń wyciągowych. Katowice: Wydawnictwo Śląsk.

Kwaśniewski, J. (2010). Badania magnetyczne lin stalowych. Kraków: Wydawnictwo Akademii Górniczo Hutniczej.

Mazur, S. (2015). Analiza trwałości lin nośnych i wyrównawczych eksploatowanych w wyciągach szybowych KWK Bielszowice. Praca dyplomowa. Gliwice: Instytut Mechanizacji Górnictwa Politechniki Śląskiej.

Szklarski, L. and Zarudzki, J. (1998). Elektryczne maszyny wyciągowe. Warszawa: Wydawnictwo Naukowe PWN.

Tytko, A. and Nowacki, J. (2010). Abrasive wear of external wires of mining hoist ropes. The International Journal of Transport and Logistics, pp. 101-105.

Tytko, A. (2003). Eksploatacja lin stalowych. Katowice: Wydawnictwo Śląsk.

Wojczyk, J. (2005). Górnicze urządzenie wyciągowe wielolinowe z linami nośnymi płaskimi stalowo-polimerowymi. Praca dyplomowa. Gliwice: Instytut Mechanizacji Górnictwa Politechniki Śląskiej.

Żur, T. and Hardygóra, M. (1996). Przenośniki taśmowe w górnictwie. Katowice: Wydawnictwo Śląsk. 


\begin{abstract}
.
The paper presents the development of a series of flat steel and polymer bearing ropes using a polyurethane polymeric material (the name of NPSP - flat steel-polyurethane). These ropes are intended for mining extraction devices with friction drive (multi-mill drive wheel, multi-rope drums with a number of ropes from 3 to 12 pieces). The authors of this article have presented a comparison of the drive power of a selected multi-mine mine hoist device with a classic steel round rope with the same extractor in which steel and polymer flat carrying ropes were used. The article also presents the development of mining construction of hoisting equipment, which includes the use of new rope ropes. Very positive results from exploitation in Polish mining of flat steel-rubber balance ropes (durability up to 12 years) can be the basis for the use of such ropes as supporting ropes. Flat steel-polymer supporting ropes, in which the matrix can be rubber or polyurethane or other plastic material, could contribute to increasing the durability of load-bearing ropes due to anti-corrosion protection as well as to reduce the dimensions of drive wheels and rope hoisting machines, and thus to lower the power of the winding machine (as a result of reducing the moments of inertia of the propeller, propulsion and rope). It is also worth mentioning that the NPSP carrying ropes can work directly on steel coatings of propeller drums with proper positioning, created by clamping elements (wood, plastic or aluminum blocks).
\end{abstract}

Keywords: ropes, flat, polymer, polyurethane 